\title{
Associations between pycnogonids and hydroids from the Buenos Aires littoral zone, with observations on the semi-parasitic life cycle of Tanystylum orbiculare (Ammotheiidae)*
}

\author{
GABRIEL N. GENZANO \\ Departamento de Ciencias Marinas. Facultad de Ciencias Exactas y Naturales. Universidad Nacional de Mar del Plata. \\ CONICET. Funes 3250 (7600) Mar del Plata. ARGENTINA. E-mail: genzano@mdp.edu.ar
}

\begin{abstract}
SUMMARY. Abundance and seasonality of Tanystylum orbiculare Wilson, 1878 populations (Pycnogonida; Ammotheidae) associated with Sarsia sarsii (Loven, 1836) and Tubularia crocea (Agassiz, 1862) (Hydrozoa; Anthomedusae) are analysed and the semi-parasitic life cycle of this species is described. In the analysed population, the first larval stages were found exclusively as parasites of $S$. sarsii. During the attachment to the hydranths, protonymphon larvae of $T$. orbiculare feed by sucking the hydranths of the cnidarian. Change of host is not obligatory; juveniles and adults were found both on $S$. sarsii as on T. crocea, and adults were also observed on other invertebrates. In the Mar del Plata intertidal, Tanystylum orbiculare was the most common pycnogonid species on colonies of T. crocea and S. sarsii. Anoplodactylus petiolatus was less abundant on both species and A. assimilis was found only on T. crocea. Endeis spinosa is absent on hydroids from the Mar del Plata intertidal zone but ectoparasitic larvae and adults were found on Obelia longissima colonies from Mar del Plata harbour together with adults of T. orbiculare and A. petiolatus. Endoparasitic larvae of A. petiolatus were found associated with colonies of Bougainvillidae.
\end{abstract}

Key words: hydroids, pycnogonids, association, parasitism, Argentina.

\section{INTRODUCTION}

Pycnogonids can be found in all marine habitats from the intertidal zone to abyssal depths. Although they are distributed worldwide, little is known about their biology.

Pycnogonids are usually found associated with other animals, the large majority of these associations involving sessile or sluggish invertebrates as food (Bain, 1991; Piel, 1991; Varoli, 1994 and others). The commonest recorded associates are cnidarians, including sea anemones (Mercier and Hamel,

\footnotetext{
*Received January 9, 2001. Accepted September 4, 2001.
}

1994) and especially hydroids (Staples and Watson, 1987; Staples, 1997) in which pycnogonid larvae often live as parasities within tissues of the colonies. Medusae records are relatively rare (Child and Harbison, 1986).

Although their larvae were described earlier, only recently has it been possible to describe the life cycle and population dynamics of some species (King and Jaervis, 1970; Munilla, 1979, 1980; Tomaschko, et al., 1997; Wilhelm, et al., 1997).

The pycnogonida of the Argentina continental shelf are poorly known. The available taxonomic accounts analysed species from the intertidal zone, harbour areas, and a few deep water samples of 
Buenos Aires province, and from the north-Patagonian sector (Río Negro province) (Castellanos, 1965; Stock, 1966; Larramendy, 1974; 1975; Larramendy and Castellanos, 1978; Minnard and Zamponi, 1984; Bremec et al., 1986). Some species were reported as part of fouling communities (Bastida et al., 1981; 1997) or as fauna associated to hydropolyps (Zamponi and Genzano, 1992) but there are no studies about their reproduction and larval stages.

Associations between pycnogonids and hydropolyps have been reported infrequently due to the few ecological studies on hydroids conducted in the intertidal fringe of Mar del Plata (Genzano, 1994 and subsequent). However, in recent years, studies on other intertidal and sublittoral hydroid communities have contributed more information on this association. In this paper, the pycnogonids found on hydroids in Mar del Plata are examined.

Abundance and seasonality of Tanystylum orbiculare Wilson, 1878 populations (Pycnogonida; Ammotheidae) associated with Sarsia sarsii (Loven, 1836) and Tubularia crocea (Agassiz, 1862) (Hydrozoa; Anthomedusae) are reported here and the semi-parasitic life cycle of the pycnogonid is described.

Records of association between hydroids and pycnogonids from other locations in the province of Buenos Aires were also analysed.

\section{MATERIALS AND METHODS}

This study results from numerous samples carried out since 1989 from the intertidal rocky shore and from a smaller data set from the sublittoral rocky bottom of Mar del Plata, Argentina. Information on association between hydroids and pycnogonids from other areas in Buenos Aires province were also included here.

Studies on taxonomic composition and abundance of pycnogonids were carried out in samples of Sarsia sarsii and Tubularia crocea colonies from the Punta Cantera intertidal $\left(38^{\circ} 05^{\prime} \mathrm{S} 57^{\circ} 32^{\prime} \mathrm{W}\right)$, which were collected at monthly or bimonthly intervals from October 1989 to February 1992. After this period, colonies were monitored at irregular intervals until October 2000.

Pycnogonids were separated under a stereomicroscope and were identified according to Marcus (1940) Minnard and Zamponi (1984) and Bremec et al. (1986).
Sarsia sarsii is a common epizoic hydroid on the mytilid Brachydontes rodriguezi (d'Orbigny, 1846). Each sampled "clump" living on a bivalve was considered as one colony and the abundance of pycnogonids was indicated as number of individuals per colony. The relative abundance of the different larval stages within the population of Tanystylum orbiculare was observed. Due to the small size and cryptical colour of parasitic protonymphon larvae, which were attached among capitate tentacles, their abundance was estimated by counting under the microscope the larvae attached to 50 hydranths selected at random from each sample.

Abundances of pycnogonids associated on $T$. crocea were indicated as numbers of individuals $/ \mathrm{g}$ colony dried for $48 \mathrm{~h}$ at $35-40^{\circ} \mathrm{C}$. Pycnogonids found on other hydroid species were indicated only as present.

Colonies of Obelia longissima (Pallas, 1766) were collected seasonally in Mar del Plata Harbour (2-3 m depth) from spring 1999 to winter 2000. Collection data on other hydroids studied are indicated in the text.

\section{RESULTS}

\section{Association between pycnogonids and hydroids in the Mar del Plata intertidal}

During this study, a total of 503 pycnogonids associated with $T$. crocea and $S$. sarsii colonies were observed. Due to the abundance of $T$. crocea in the intertidal fringe, most pycnogonid specimens were found on this species. However, there were seasonal changes: $S$. sarsii was the more frequent host in autumn and $T$. crocea was the more frequent host in the cold months when $S$. sarsii was scarse or absent (Fig. 1).

Tanystylum orbiculare (Ammotheidae) was the dominant pycnogonid on both species of hydroids. This ammotheid occurred throughout the year, with maximum numbers in summer and autumn correlating with warm water temperatures. Anoplodactylus petiolatus (Kroyer, 1844) (Phoxichilidiidae) was less abundant on T. crocea and occasional on S. sarsii. Achelia assimilis (Haswell, 1885) (Ammotheidae) was found only on T. crocea (Figs. 2 and 3).

Tanystylum orbiculare was occasionally found also on Plumularia setacea (Linnaeus, 1758) (Leptomedusae), another hydrozoan sharing the intertidal habitat with $T$. crocea and $S$. sarsii, but only during the warm seasons (Genzano, 1994). 


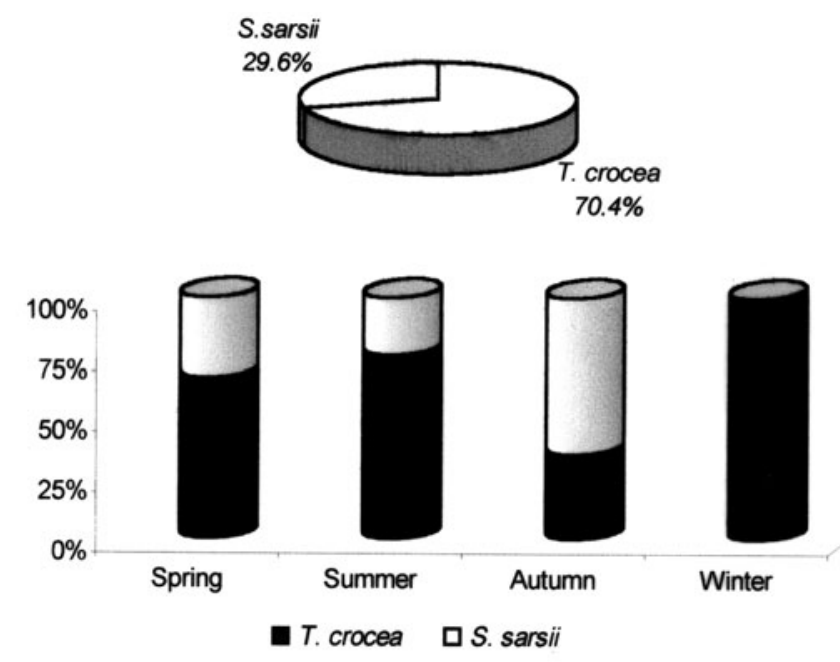

FIG. 1. - Frequency of hydroids as substrata of pycnogonids from Mar del Plata rocky intertidal.

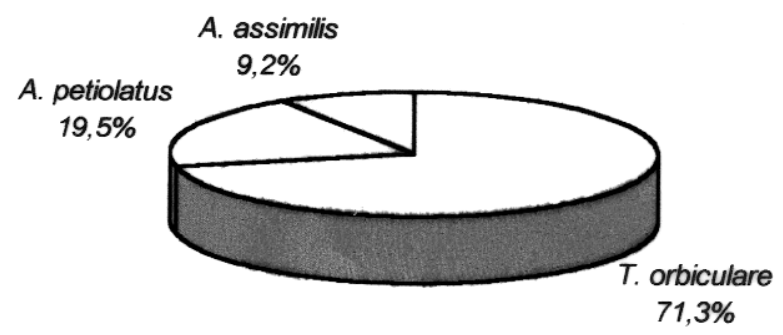

A. petiolatus

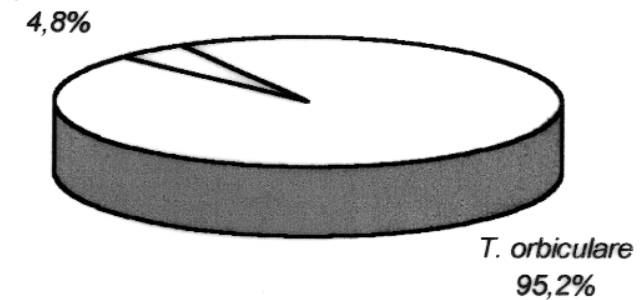

FIG. 2. - Frequency of pycnogonids associated with: a) Tubularia crocea and b) Sarsia sarsii.
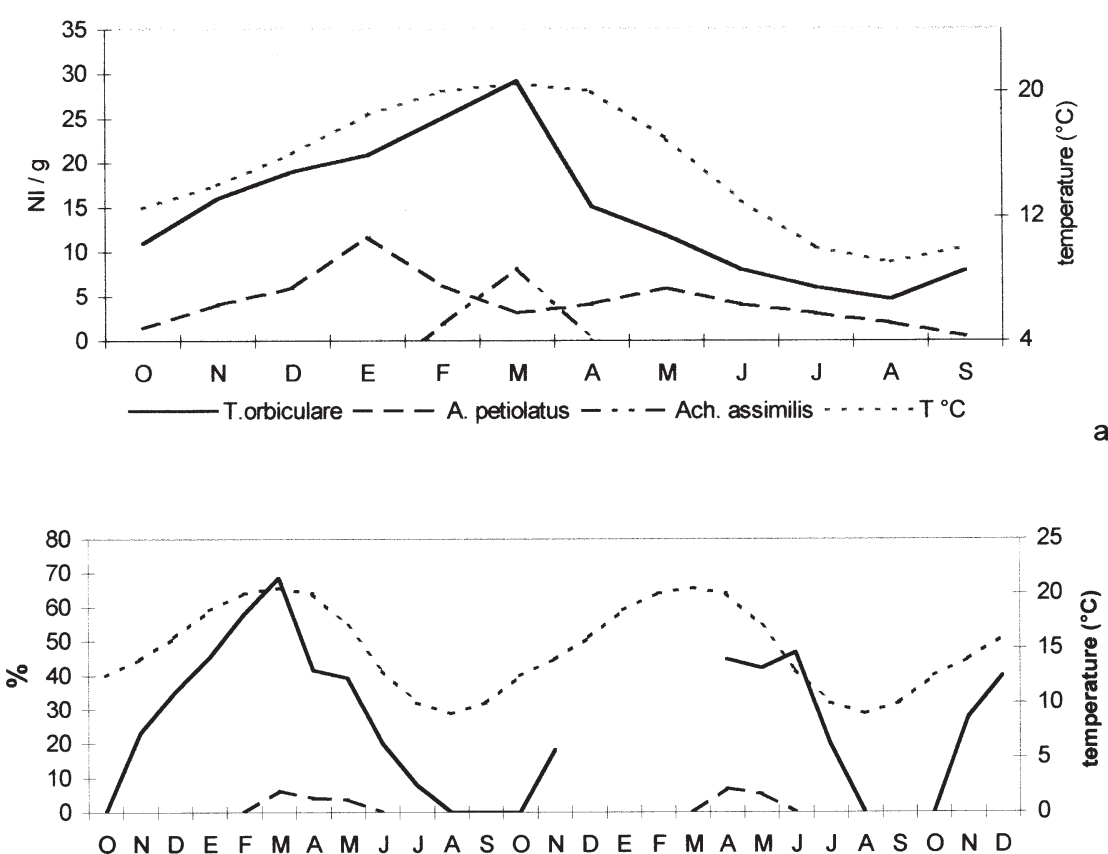

- T. orbiculare --- A. petiolatus $\cdots .-\mathrm{T}^{\circ} \mathrm{C} \quad$ b

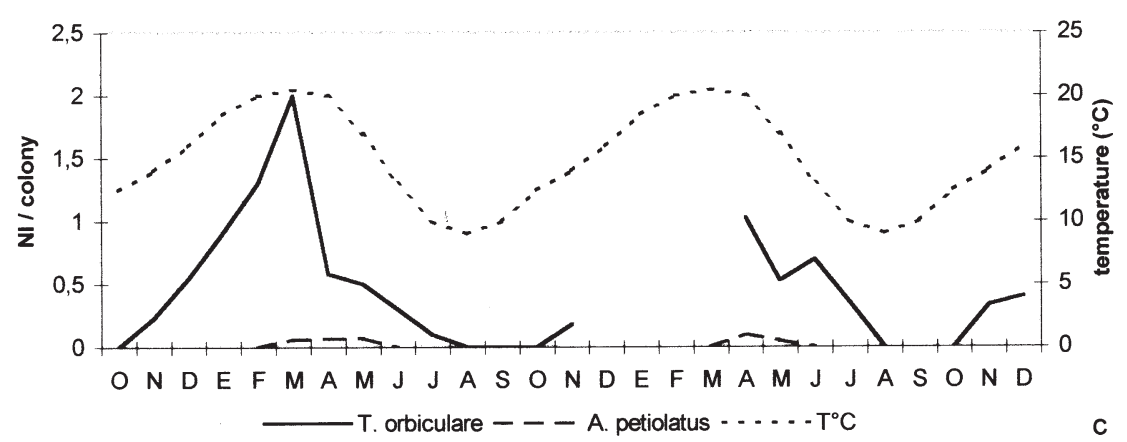

FIG. 3. - Abundance of pycnogonids on: a) Tubularia crocea (number of pycnogonids / g. colony), b) Sarsia sarsii (frequency of colonies with pycnogonids) and c) Sarsia sarsii (number of pycnogonids/colony). 
Other hydroid species from this intertidal fringe were scarce, often occurring as small epizoic colonies on T. crocea (Genzano, 1994; 1998, Genzano and Rodriguez, 1998). No pycnogonids were associated with any of those species except Bimeria vestita Wright, 1859 (see below).

\section{Post embryonic development of Tanystylum orbiculare}

Records of $T$. orbiculare specimens were not frequent enough to estimate the relative abundances of all developmental stages (juveniles, mature females, mature ovigerous males, etc.). However, relative abundances and frequency of larval stages on different host colonies helped to gather information on the life cycle of this pycnogonid.

Pycnogonids are one of few groups of animals in which the males exclusively care for the developing eggs. Tanystylum orbiculare males carrying egg batches on the ovigerous legs were found throughout the year on both $S$. sarsii and on $T$. crocea.

Males carried the eggs until hatching. The protonymphon larvae (the first larval stages) leave the male and become associated with $S$. sarsii hydranths. The few males observed carrying protonymphon larvae suggested that attachment to hydranths occurs shortly after hatching.

The protonymphon larvae were present among the capitate tentacles of hydranths and their tegument provided a defense against the nematocyts. The colour (brown) matched that of the hydranths. The larvae were characterised by a small proboscis flanked by chelate cheliphores. Two pairs of clawed lateral appendages were present. Body length ranged from 121 to $202 \mu$ (Figs. $4 a$ and 5a-b).

During the study period, the protonymphon larvae occurring on a total of 900 hydranths of $S$. sarsii were analysed. Larvae were found from October to June, with maximum numbers from November to March (Fig. 6).

The subsequent larval stage resembled the protonymphon, but the cheliphores were shorter and it was characterized by the appearance of the first permanent legs (Figs. 4b and 5c). Other stages, found either on hydranths or on the hydrocaulus of $S$. sarsii, possessed the second and third pair of legs (Figs. 4c-d and 5d).

Free-living juvenile stages were found not only on $S$. sarsii but also on $T$. crocea colonies. The major changes during metamorphosis to the first juvenile stages is the disappearence of the cheliphores. In the
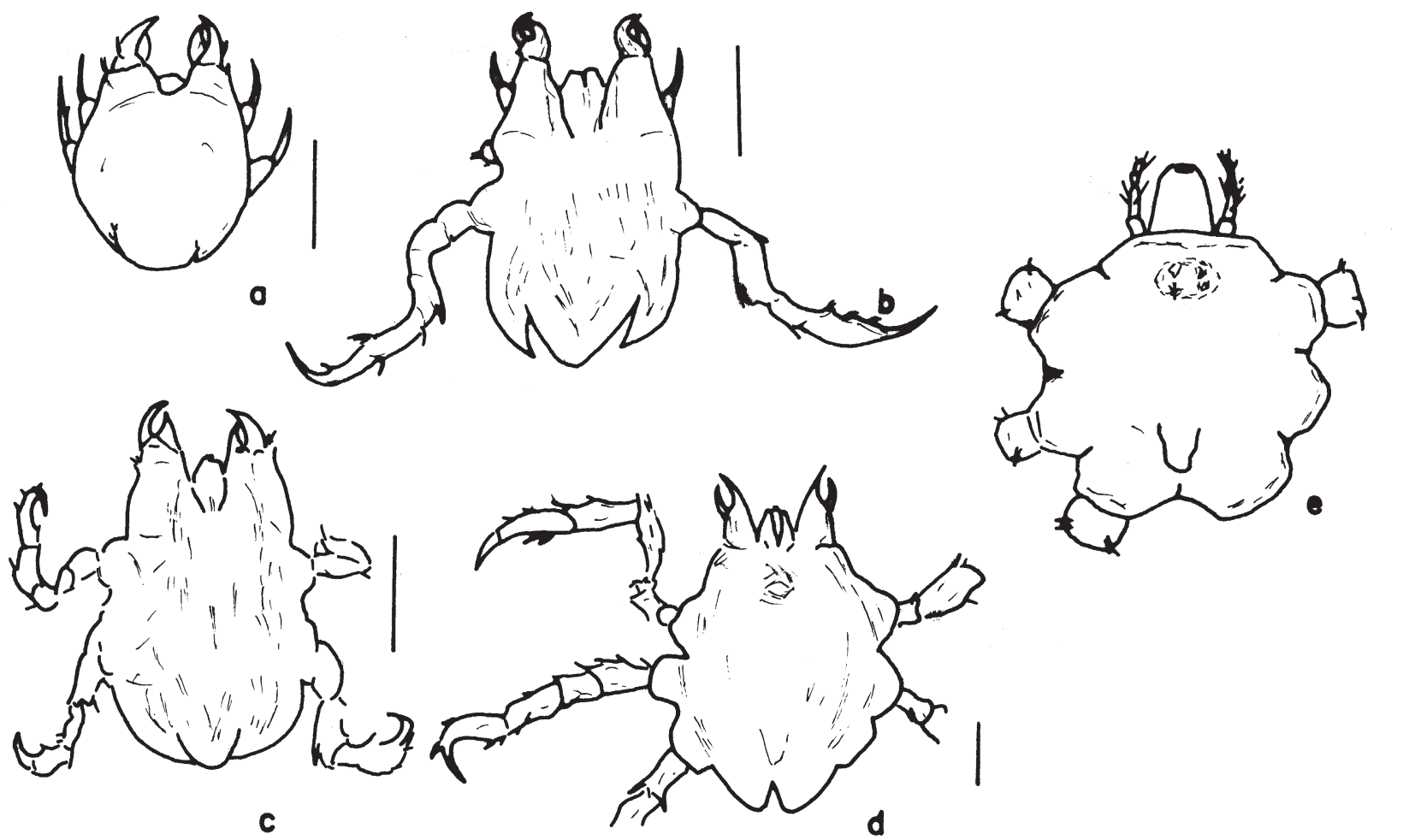

FIG. 4. - Tanystylum orbiculare: a) protonymphon larva, b, c and d) Larval stages with the first, second and third pairs of permanent legs respectively. e) Juvenile stage. Scale bar $=100 \mu$. 

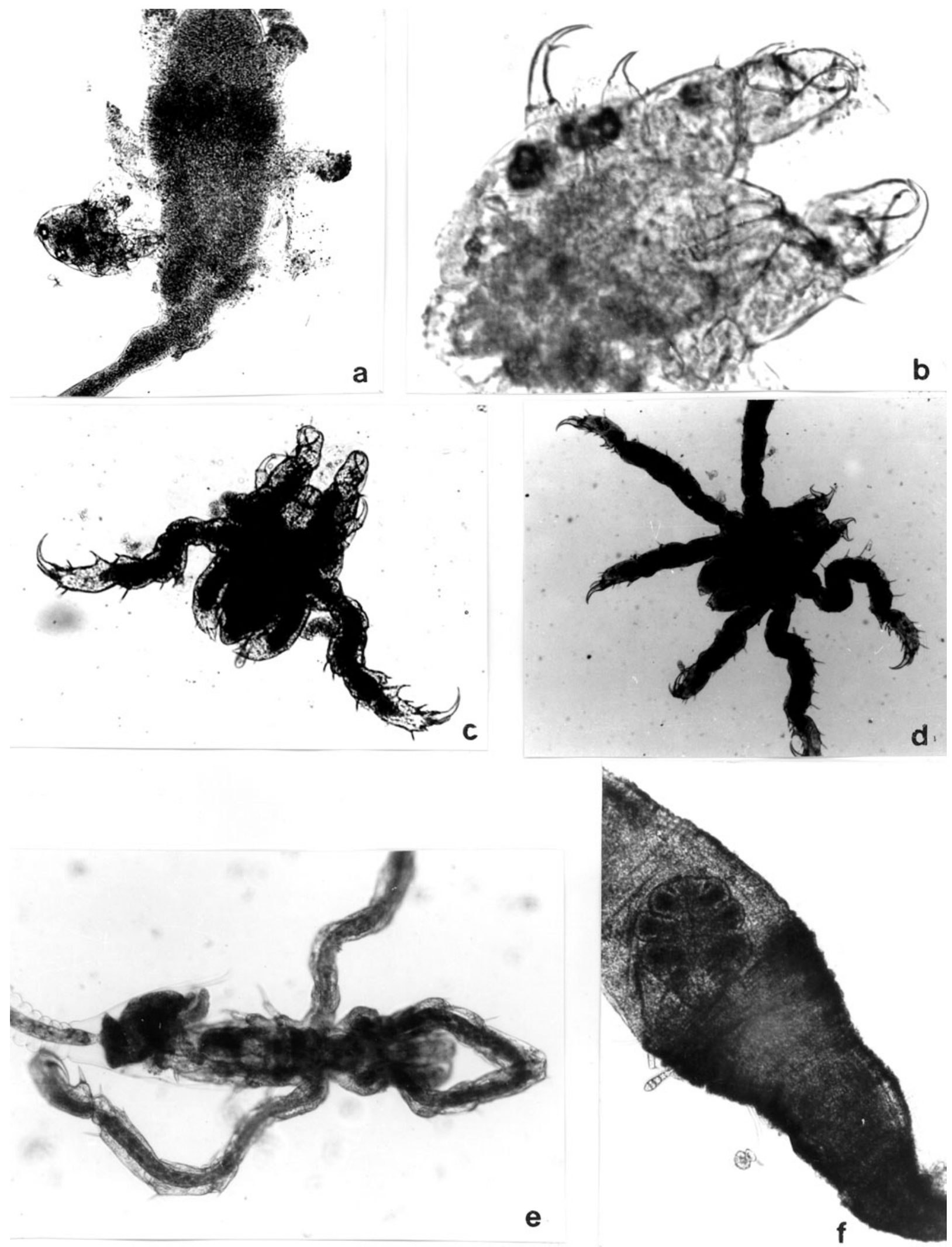

FIG. 5. - a) Protonymphon larva of Tanystylum orbiculare attached to hydranth of Sarsia sarsii (100 x), b) Detail of protonymphon larva (400 $\mathrm{x})$, c) Larva stage of Tanystylum orbiculare with the first pair of permanent legs $(40 \mathrm{x})$, d) Larva stage with the three pairs of permanent legs $(40 \mathrm{x})$, e) Ectoparasitic larva of Endeis spinosa in hydrotheca of Obelia longissima $(100 \mathrm{x})$, f) Endoparasitic encysted larva of a Phoxichilididae producing deformation of Bimeria vestita hydranth $(40 \mathrm{x})$. 


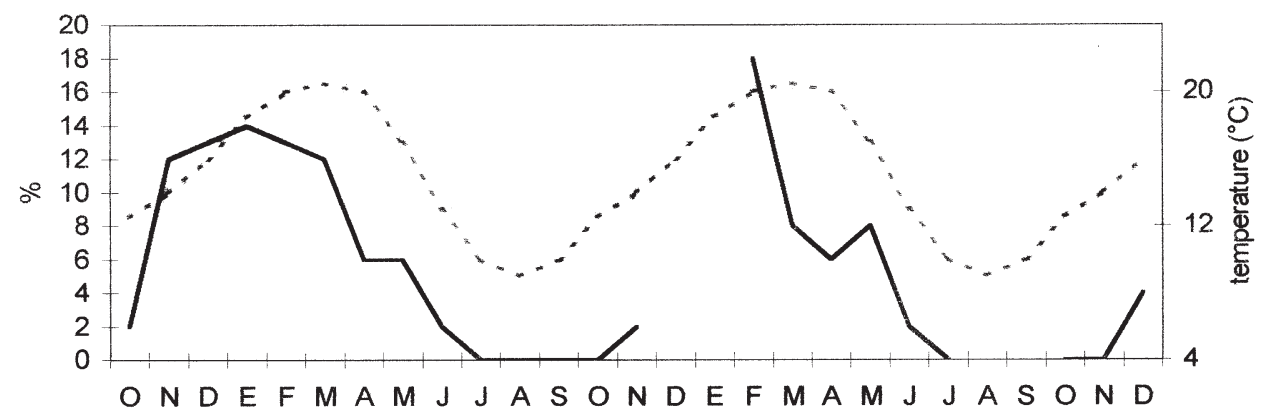

FIG. 6. - Frequency of hydranths of Sarsia sarsii with ectoparasitic protonymphon larvae of Tanystytlum orbiculare.

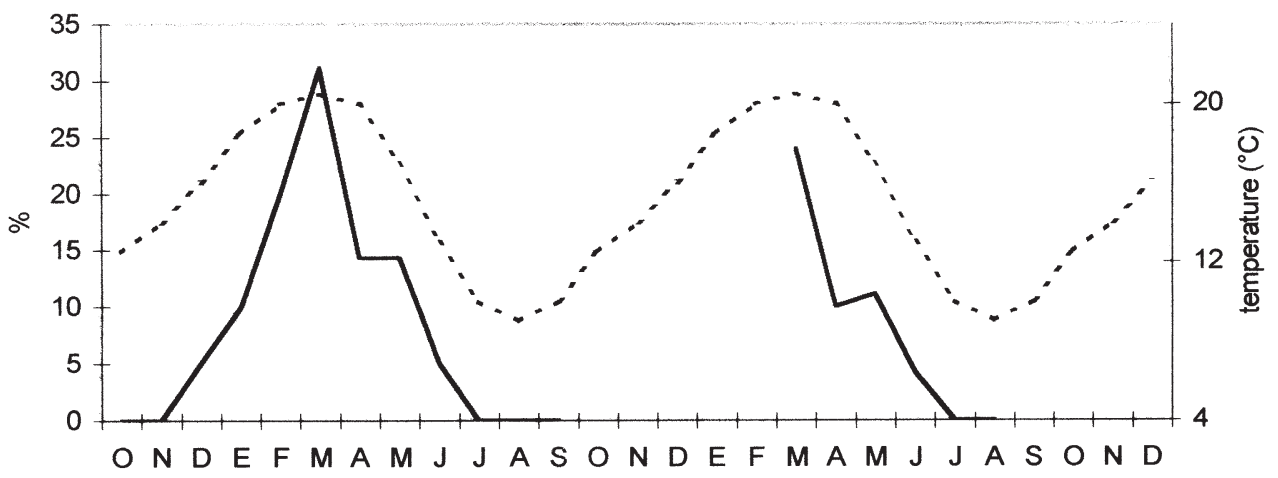

FIG. 7. - Frequency of juvenile stages of Tanystylum orbiculare on Sarsia sarsii colonies.

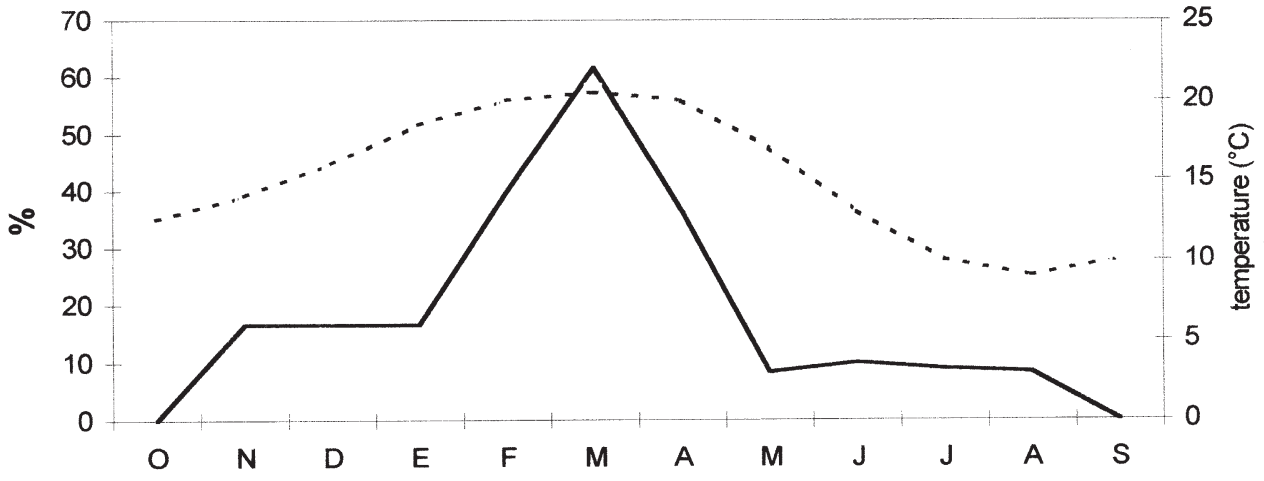

FIG. 8. - Frequency of juvenile stages of Tanystylum orbiculare on Tubularia crocea colonies.

last juvenile stage, the specimens developed the final large proboscis, which was significantly larger than the larval proboscis, and lost their larval extremities, retaining three pairs of walking legs and then adding the fourth pair. Body length varied considerably from 1.5 to $2.4 \mathrm{~mm}$ (Fig. 4e). The first juvenile stages appeared from November to August, with a peak in late summer (Figs. 7 and 8).

The last juvenile stages had four pairs of permanent legs. Adults can be distinguished from them by the genital pores and by the fully developed oviger in males. The adults were usually covered with mud particles and diatoms which acted as a camouflage.
Last juveniles and adults occurred all year on both hydroid species.

\section{Other ecto-parasitic larvae}

Colonies of Obelia longissima, epizoites on ascideans, are abundant in Mar del Plata harbour. Adult pycnogonids of Tanystylum orbiculare, Anoplodactylus petiolatus, and Endeis spinosa (Montagu, 1808) were associated with these colonies. During summer only (March 13, 2000), a few hydranths were infested by parasitic larvae inside the hydrothecae. These larvae were assigned to Endeis spinosa. 


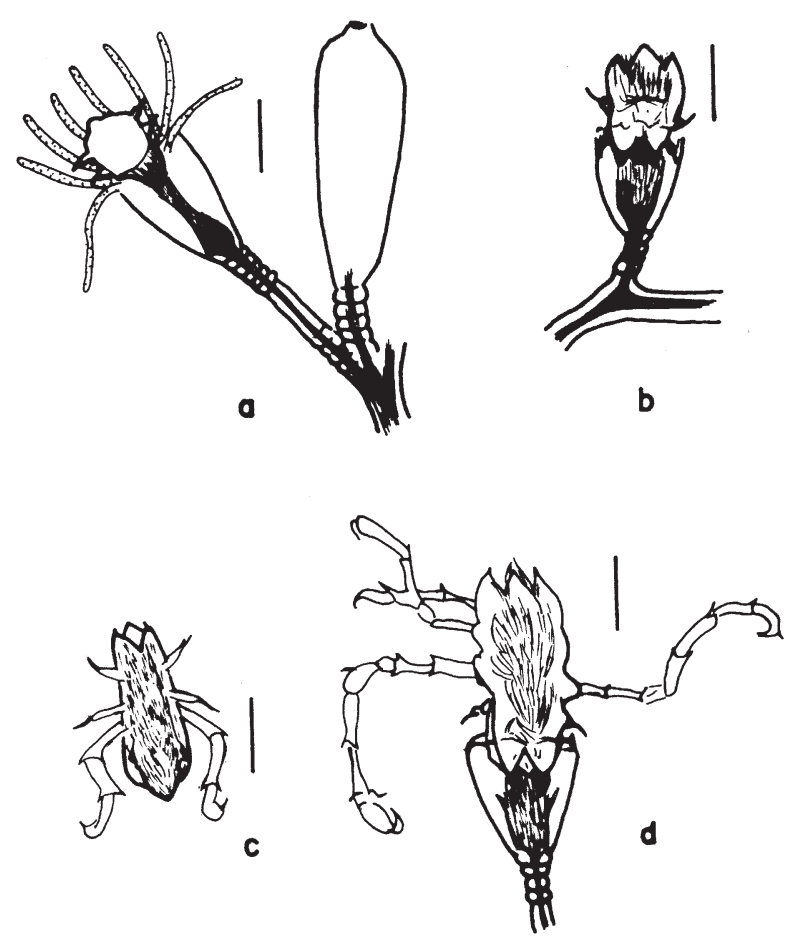

FIG. 9. - a, b) Protonymphon larvae of Endeis spinosa in hydrothecae of Obelia longissima. c, d) Larvae with the first and second pairs of permanent legs, respectively. Scale bar: $200 \mu \mathrm{m}$.

Protonymphon larvae were found among filiform tentacles of the hydranths (Figs. 9 a-b). Permanent legs developed progressively in late larval stages (Figs. 9c-d and 5e).

Helfer (1932; in Staples and Watson, 1987) recorded larvae of Anoplodactylus pygmaeus (Hodge, 1862) attached to the hydranths of Obelia sp. without any obvious deformation on the hydrotheca. Howevere, some of the E. spinosa larvae observed here had destroyed the hydrothecae and the last large permanent legs projected out of them.
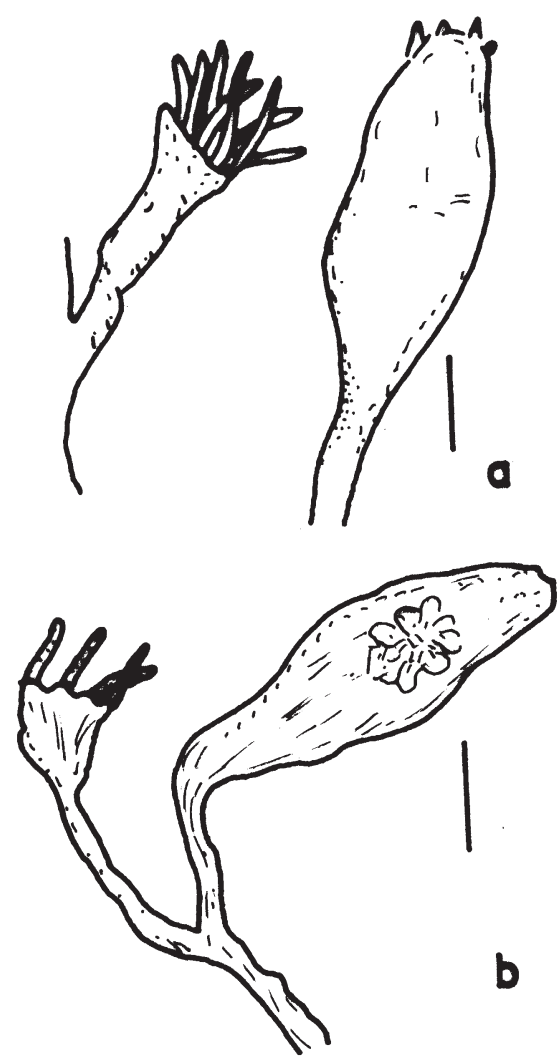

FIG. 10. - Endoparasitic encysted larva of a Phoxichilididae into hydranths of: a) Bougainvillia muscus (scale bar: $500 \mu \mathrm{m}$ ) and b) Bimeria vestita (scale bar: $1000 \mu \mathrm{m})$.

\section{Endo-parasitic larvae}

The larval type to hatch from the eggs is the protonymphon. Usually, after leaving the male's ovigerous legs, the protonymphon undergoes a series of moults during which it adds appendages until the adult number of appendages has been reached (Marcus, 1940; Tomaschko et al., 1997; Wilhelm et al., 1997).

TABLE 1. - Records of associations of pycnogonids with hydroids in the Buenos Aires littoral (records from the literature are indicated between bracket). T.o: Tanystylum orbiculare Wilson, 1878; A.a: Achelia assimilis (Haswell, 1885); A.p: Anoplodactylus petiolatus (Kroyer, 1844); A.s: Anoplodactylus stictus Marcus, 1940; E.s: Endeis spinosa (Montagu, 1808); e.1: encysted larva.

\begin{tabular}{|c|c|c|c|c|c|c|}
\hline & \multicolumn{2}{|c|}{ Ammotheidae } & \multicolumn{3}{|c|}{ Phoxichilididae } & \multirow{2}{*}{$\begin{array}{c}\text { Endeidae } \\
\text { E.s. }\end{array}$} \\
\hline & T.o & A.a & A. $p$ & e 1, A.p & A.s & \\
\hline \multicolumn{7}{|l|}{ Anthomedusae: } \\
\hline Sarsia sarsii & 1 & 1 & - & - & - & - \\
\hline Bimeria vestita & - & - & - & 1 & - & - \\
\hline Bougainvillia muscus & (4) & - & 4 & (4) & - & (6) \\
\hline Tubularia crocea & 1 & 1 & $1,(6)$ & - & (6) & (6) \\
\hline \multicolumn{7}{|l|}{ Lepthomedusae: } \\
\hline Obelia longissima & 2,3 & - & 2 & - & - & 2 \\
\hline Obelia sp. & - & $(6)$ & - & - & - & - \\
\hline Amphisbetia operculata & 3 & 3 & - & - & - & - \\
\hline Plumularia setacea & $1,(5)$ & (6) & - & - & - & - \\
\hline
\end{tabular}

1: $38^{\circ} 05^{\prime} \mathrm{S} 57^{\circ} 32^{\prime} \mathrm{W}$, Mar del Plata, intertidal; 2: Mar del Plata, Harbor, 2-3 m depth; 3: Mar del Plata sublittoral rocky botton, $\left.6 \mathrm{~m}\right)$; 4 :

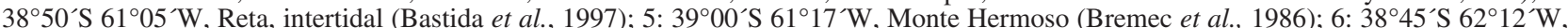
Ingeniero White Harbor (Bremec et al., 1986). 
In another less frequent pathway of development, larvae acquire endoparasitic behaviour in a hydranth, undergoing one or more moults (exact number unknown), and emerging as juveniles. These endoparasitic larvae usually produce deformed hydranths. The manner in which the larvae locate and penetrate the hydranths is unknown (see Staples and Watson, 1987 for a review).

In the Buenos Aires littoral zone, endoparasitic larval was found in two athecate hydroids (Bougainvillidae): Bimeria vestita (Wright, 1859) and Bougainvillia muscus (Van Beneden, 1844).

Many epizoic colonies of $B$. vestita from the Mar del Plata intertidal were studied over more than a decade (Genzano, 1998; Genzano and Zamponi, 1999) but only recently (samples from March and October, 2000) have endo-parasitic Phoxichilidiidae larvae (possibly Anoplodactylus petiolatus) been found in four hydranths.

Bougainvilla muscus colonies were recorded in different places from Buenos Aires littoral (Genzano, 1995: B. ramosa). Different adult pycnogonids were found associated with them (see Table 1), and endoparasitic larvae of $A$. petiolatus were found in some hydranths of colonies from the intertidal at Reta (Bastida et al, 1997: B. ramosa).

In both athecate hydroids a few dilated hydranths with their tentacles stunted or absent were observed. Pycnogonid larvae occupied these hydranths and were the cause of their deformation (Figs. $5 f$ and 10a-b).

Larvae of pycnogonids in the coelenteron of $T$. crocea were reported by Staples and Watson (1987), but there was no evidence of such an infestation in the tubularids studied here.

\section{Records of associations of pycnogonids to hydroids in the Buenos Aires area}

Pycnogonids associated with athecate and thecate hydroids are shown in Table 1 . There were 20 records of pycnogonids associated with eight hydroid species, mostly $T$. crocea and $B$. muscus.

The Ammotheidae (T. orbiculare and A. assimilis) were the pycnogonids most frequently found on hydroid colonies.

\section{DISCUSSION AND CONCLUSION}

Few studies have analysed the taxonomic composition of pycnogonids from Buenos Aires province and the north-Patagonian sector (Río
Negro province) on the Argentina continental shelf (Castellanos, 1965; Stock, 1966; Larramendy, 1974; 1975; Larramendy and Castellanos, 1978; Minnard and Zamponi, 1984; Bremec et al., 1986), none of them dealing with pycnogonid ecology and reproductive biology. Studies on hydroid populations from the Mar del Plata intertidal zone provided information on associated pycnogonids and on their seasonal dynamics.

Tanystylum orbiculare was the most common pycnogonid species on colonies of $T$. crocea and $S$. sarsii. Anoplodactylus petiolatus was less abundant on both species, and A. assimilis was found only on T. crocea. Endeis spinosa was absent on hydroids from the Mar del Plata intertidal, but ectoparasitic larvae and adults were found on Obelia longissima colonies from Mar del Plata harbour together with adults of T. orbiculare and A. petiolatus. From deeper water, only epibionts on Amphisbetia operculata (L.) colonies were analysed, and few adults of $T$. orbiculare were found there.

The absence of pycnogonid records on hydroids belonging to some hydrozoan families (e.g. Haleciidae, Lafoeidae) is probably due to the rarity of representatives of these families in the study area (Genzano and Zamponi, 1997). Except for the well-studied thecate A. operculata (Sertulariidae), information on large sublittoral thecate colonies are still scant.

Bastida et al. (1997) reported, from another intertidal location in Buenos Aires, that A. petiolatus was the most common pycnogonid on Bougainvillia muscus colonies, and encysted larvae of this species were only found associated with Bougainvillidae colonies (see Table 1). These observations suggest that species-specific associations between pycnogonids and hydroids may occur, supporting the observations of other authors (Staples and Watson, 1987; Tomaschko et al., 1997; Wilhelm et al., 1997).

The interactions of pycnogonids with their invertebrate hosts and their life cycles are still poorly known. In Pycnogonum litorale Strom, the first larva stage is ectoparasite on the hydroid Clava multicornis (Forskal, 1775); and the metamorphosis to juvenile is accompanied by an obligatory change of host from the hydroid to the sea anemone Metridium senile (Linneus, 1767) (Tomaschko et al., op cit.; Wilhelm et al., op cit.).

Observations on larval stages of $T$. orbiculare, and on their host, allowed the life cycle of this pycnogonid to be reconstructed (Fig. 11). In the analysed population, the first larval stages were 


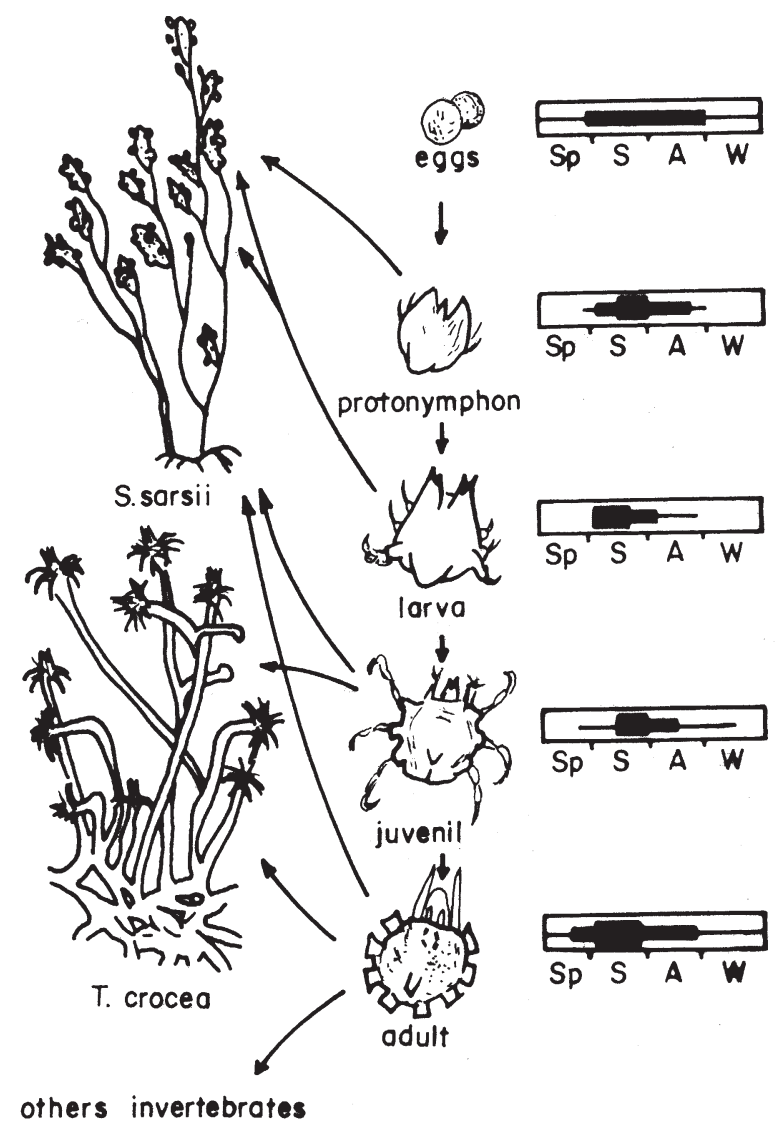

FIG. 11. - Life cycle diagram of Tanystylum orbiculare (see text for more details).

found exclusively as parasites of $S$. sarsii.

Change of host is not obligatory in this species, as juveniles and adults were found both on S. sarsii and on T. crocea. Adults were also reported on other invertebrates, such as the sponge Hymeniacidon sanguinea Grant, 1827 (Cuartas and Excoffon, 1993 ) in the community associated with the small mussel Brachydontes rodriguezi (d'Orbigny, 1846) (Scelzo et al., 1996), and on organisms associated with the sea anemone Anthothoe chilensis (Lesson, 1830) (Excoffon, et al., 1999).

Very little is known about pycnogonid feeding habits. Some species are generalized predators that feed on hydroids, polychaetes, nudibranchs and other invertebrates (Bain, 1991, Piel, 1991, Varoli, 1994).

During the attachment to the hydranths, protonymphon larvae of $T$. orbiculare feed by sucking. Some nematocysts (stenoteles) were found in their proboscides.

Adults were found browsing on hydroids and on their hydrocauli, where many protists and diatoms live as epizoites of the colonies (Zamponi and Genzano, 1992).
Futher studies about the life cycle of T. orbiculare under laboratory conditions will be of interest to ascertain the number of instars and moults, and the duration of each larval stage up to maturity.

\section{ACKNOWLEDGEMENTS}

I wish to thank Dr. Calder (Royal Ontario Museum, Canada) for his critical revision of the manuscript and linguistic help. Cordial thanks are also due to Dr. Zamponi (FCEyN-UNMdP) for his comments and Dr. Bastida and Lic. Martín (FCEyNUNMdP) for providing colonies of Bougainvillia muscus from the intertidal zone at Reta.

\section{REFERENCES}

Bain, B.A. - 1991. Some observations on biology and feeding behavior in two southern California pycnogonids. Bijdr. Dierk., 61(1): 63-64.

Bastida, R., M. Trivi de Mandri, V. Lichtschein de Bastida and M. Stupak. - 1981. Ecological aspects of marine fouling at the port of Mar del Plata, Argentina. Actas del Congreso Internacional de Corrosión Marina e Incrustaciones, 5, España: 299-320.

Bastida, R., J.P. Martin and E. Ieno. - 1997. Comunidades incrustantes de areas costeras del sur de la provincia de Buenos Aires (Argentina). Cidepint-Anales, 1997-1998: 171-197.

Bremec, C.S., D.E. Martinez and R. Elias. - 1986. Picnogónidos de los alrededores de Bahía Blanca (Argentina). Spheniscus, 3: 31-49.

Castellanos, Z.J.A. - 1965. Adiciones a la pantopodofauna Argentina. Physis, 25(69): 13-17.

Child, C.A. and G.R. Harbison. - 1986. A parasitic association between a pycnogonid and a scyphomedusae in midwater. $J$. Mar. Biol. Ass. U. K., 66: 113-117.

Cuartas, E. and A.C. Excoffon. - 1993. La fauna acompañante de Hymeniacidon sanguinea (Grant, 1827) (Porifera: Demospongiae). Neotropica, 39(101-102): 3-10.

Excoffon, A.C., G.N. Genzano and M.O. Zamponi. - 1999. Associated macrobenthos to a population of Anthotoe chilensis (Lesson, 1830) (Cnidaria, Actinaria) from Mar del Plara Harbour, Argentina. Cienc. Mar., 25(2): 177-191.

Genzano, G.N. - 1994. La comunidad hidroide del intermareal rocoso de Mar del Plata (Argentina). I. Estacionalidad, abundancia y períodos reproductivos. Cah. Biol Mar., 35(3): 289303.

Genzano, G.N. - 1995. New records of hydropolyps (Cnidaria) from south western Atlantic Ocean. Misc. Zool., 18: 1-8.

Genzano, G.N. - 1998. Hydroid epizoites on Tubularia crocea (Agassiz, 1862) and Sertularella mediterranea Hartlaub, 1901 (Hydrozoa-Cnidaria) from intertidal of Mar del Plata (Argentina). Russ. J. Mar. Biol., 24(2): 123-126.

Genzano, G.N. and G.M. Rodriguez. - 1998. Associations between hydroid species and their substrates from intertidal of Mar del Plata (Argentina). Misc. Zool., 21(1): 21-29.

Genzano, G.N. and M.O. Zamponi. - 1997. Frequency of study and diversity of benthic Hydrozoa of the Argentine Continental Shelf. Cienc. Mar., 23(3): 285-302.

Genzano, G.N. and M.O. Zamponi. - 1999. Natural history of Bimeria vestita Wright, 1859 (Hydrozoa, Bougainvillidae) from rocky intertidal of Mar del Plata (Argentina). Cienc. Mar., 25(1): 63- 74 .

King, P.E. and J.H. Jaervis. - 1970. Egg development in a littoral pycnogonid Nymphon gracile. Mar. Biol., 7: 294-304.

Larramendy, M.L. - 1974. Anotaciones sobre Colossendeis geoffroyi (Mañe-Garzon, 1944). Neotrópica, 20(63): 149-152.

Larramendy, M.L. - 1975. Un nuevo Pallenopsis Wilson, 1881 para 
el Mar Argentino (Pycnogonida, Pallenidae). Neotrópica, 21(65): 94-98.

Larramendy, M.L. and Z.J.A. Castellanos. - 1978. Sobre un nuevo picnogónido del Mar Argentino (Pycnogonida, Palleidae). Neotrópica, 24(72): 91-97.

Marcus, E. - 1940. Os pantopodas brasileiros e os emais sul-americanos. Bol. Facult. Filos., Ciên. Letr., 19(zool. 4): 3-179.

Mercier, A. and J. Hamel. - 1994. Deleterious effects of a pycnogonid on the sea anemone Bartholomea annulata. Can. J. Zool., 72: 1362-1364.

Minnard, V.A. and M.O. Zamponi. - 1984. Estudios sistemáticos de algunos pantópodos de la región subantártica. Historia Natural, 4(28): 257-279.

Munilla, L. - 1979. Desarrollo anual y reproducción de Achelia echinata Hodge, 1864 (Pycnogonida). Cah. Biol. Mar., 21: 115-121.

Munilla, L. - 1980. Ciclo postlarvario anual de Ammothella longipes (Hodge, 1864) (Pycnogonida). Cah. Biol. Mar., 21: 1-9.

Piel, W.H. - 1991. Pycnogonid predation on nudobranch and ceratal autonomy. Veliger, 34(4): 366-367.

Scelzo, M.A., R. Elias, E.A. Vallarino, M. Charrier, N. Lucero and F. Alvarez. - 1996. Variación estacional de la estructura comunitaria del bivalvo Brachydontes rodriguezi (d’Orbigny, 1846) en sustratos artificiales (Mar del Plata, Argentina). Nerítica, 10: 87-102.

Staples, D.A. - 1997. Sea spiders or pycnogonids (Phylum Arthropoda). In: S.A. Shepard and M. Davies (eds.), Marine Inverte- brates of Southern Australian, Part. III, pp. 1041-1072. South Australian Research and Development Institute.

Staples, D.A. and J.E. Watson. - 1987. Associations between pycnogonids and hydroids, In: J. Bouillon, F. Boero, F. Cicogna and P.F.S. Cornelius (eds.), Modern Trends in the Systematics, Ecology, and Evolution of Hydroids and Hydromedusae, pp. 215-226. Oxford University Press.

Stock, J.H. - 1966. Pycnogonida. Campagne de la Calypso au large des côtes atlantiques de 1’Amerique du sul (1961-62). In: Résultats Scientifiques de la Campagne de la Calypso, 7. Ann. Inst. Oceonogr. Monaco, 44: 385-406.

Tomaschko, K.H., E. Wilhelm and D. Buckmann. - 1997. Growth and reproduction of Pycnogonum litorale (Pycnogonida) under laboratory conditions. Mar. Biol., 129: 595-600.

Varoli, F. - 1994. Aspectos da alimantaçao de Tanystylum isabellae Marcus e Anoplodactylus stictus Marcus (Pantopoda). Rev. Brasil. Zool., 11(4): 623-627.

Wilhelm, E., D. Buckmann and K.H. Tomaschko. - 1997. Life cycle and population dynamics of Pycnogonum litorale (Pycnogonida) in a natural habitat. Mar. Biol., 129: 601-606.

Zamponi, M.O. and G.N. Genzano. - 1992. La fauna asociada a Tubularia crocea (Agassiz, 1868). (Anthomedusae; Tubulariidae) y la aplicación de un método de cartificación. Hidrobiologica, 3/4: 35-42.

Scient. ed.: J.M. Gili 